\title{
ANALYSING AND MAPPING OF LAND FIRE VULNERABILITY IN KUMPEH, MUARO JAMBI DISTRICT, JAMBI PROVINCE
}

\author{
${ }^{1}$ Farhan Kurniawan, ${ }^{2}$ Idung Risdiyanto, ${ }^{3}$ Ana Turyanti \\ ${ }^{123}$ Institut Pertanian Bogor, Bogor, Indonesia

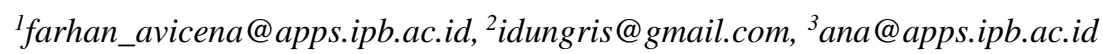

\begin{abstract}
Forest and land fires have become disasters that have received international attention. Peatland, as an important part of the forest, poses a separate threat to the effect of carbon release and climate change. Fire prevention can be done by understanding the causes. Fire vulnerability mapping uses several parameters in its calculation, namely NDVI value, NDMI value, TWI value, accessibility distance, and community activity center. Land use and hotspot history will be the parameters compared with the results of the analysis. The calculation uses a range of values from 1 to 5 . The risk level class is divided into five, with the highest percentage of $20.18 \%$ at the very vulnerable level and the lowest of $19.56 \%$ at the normal level. Very vulnerable areas have the highest number of hotspot points at 268 points, while the lowest number of hotspot points is in the safe class of 23 points. Most areas with high vulnerability are found in agriculture and plantation areas. The model used in this fire vulnerability map can be said to have a pretty good correlation.
\end{abstract}

Keywords: accessibility distance, forest fires, hotspot, land use, peatland

DOI: $10.33541 /$ sp.v21i3.2244

Sociae Polites : Majalah IImiah Sosial Politik

Faculty of Social and Political Science, Universitas Kristen Indonesia

ISSN 1410-3745 print/ ISSN 2620-4975 online

Volume 21, Number 2 (Youth Peatland Conference)

Pages 126-146 


\section{Introduction}

\subsection{Background}

Forest and land fires in Indonesia have received international attention, especially since the forest fires that occurred in the 80s (Adiningsih et al. 2005). The causes of forest and land fires are man-made rather than natural processes. Land clearing is one of the main causes of forest fires in Sumatra and Kalimantan. This was done because the forest burning method was considered cheaper and faster to implement. After the forest is burnt down, the land can be used as a plantation with the burnt ash as fertilizer. Despite its simplicity, burning land can produce many problems, such as difficulty controlling fire, fire smoke that disturbs many sectors, and threatens the survival of the wildlife that lives there.

Prevention of land fires can be done by understanding the factors that cause them. The two main factors causing land fires are climatic conditions and land management activities (BNPB 2013). The physical parameters of climate that can affect, such as micro conditions include wind direction and speed, as well as hotspot information (Nivo 2017). Human activity in managing land, for example, is the activity of clearing land by burning land. In this way, the human factor can determine the origin of the fires that appear on the ground. An understanding of the two factors is needed to make efforts to prevent land fires to take effective action.

Geographical information systems and remote sensing have long been used to support forest fire control. One form of its use is to develop a fire vulnerability map. Through this map, monitoring and fire prevention activities can be carried out as early as possible. Several methods have been formulated to determine the level of forest fire vulnerability, but its accuracy is questionable if it is applied in different areas due to variations in local conditions. Therefore, with the many cases of forest and land burning in Jebus village, Sungai Aur village, and Gedong Karya village, this research needs to be carried out to determine the level of the forest and land fire susceptibility according to local conditions.

\subsection{Purpose and Objective}

Based on the description in the background, the purpose of which the writers want to gain is to understand the area, percentage, and location of each fire vulnerability class, also determine the formula for the level of the forest and land fire vulnerability in the villages of Jebus, Sungai Aur, and Gedong Karya, Kumpeh District, Muaro Jambi Regency

\section{Literature Review}

\subsection{Forest Fire}

As one of the problems that always accompanies forest resource exploitation activities, land and forest fires in Indonesia has turned out to be a recurring incident over the past 20 years (Ulya and Yunardi 2006). Burning land without supervision causes uncontrolled fires and causes a haze disaster with serious impacts on the health sector. In the field of transportation, especially air transportation, the occurrence of delays to the cancellation of aircraft departure schedules due to very low visibility due to smog is also part of uncontrolled land burning. Forest and land fires in Indonesia are closely related to the El Nino phenomenon in the equatorial Pacific Ocean (Wooster et al., 2012). Forest and land fires in the peat areas of Sumatra and Kalimantan islands often occur during the dry season. 
Jambi Province is one of the areas with a fairly high incidence of forest and land fires and occurs almost every year. Even the incidence of forest and land fires in Jambi Province in 2015 was a special concern that opened the eyes of all parties to the seriousness of the threat and impact of this incident (Supriyanto et al., 2018). Land and forest fires can be monitored based on the distribution and number of hotspots from satellite monitoring. The peak of accumulation of hotspots in Jambi generally occurs in August September, which coincides with the dry season in most parts of Indonesia.

\subsection{Climate Change}

Climate change has an impact on various sectors in Indonesia related to people's lives. The most extreme impact of climate change is an increase in temperature and a shift in seasons. One of the real impacts of climate change on the forestry sector is the catastrophic forest fires caused by hot weather and insufficient rainfall. Climate is one of the natural factors that can cause forest and land fires because climatic conditions can affect the level of surface fuel dryness, the amount of oxygen available, and the speed at which fire spreads (Syaufina 2018). According to him also, meteorological parameters such as air temperature, relative humidity, wind, and rainfall are factors that support the high incidence of long fires in tropical countries (Syaufina 2008). In the period 1997-1998, Indonesia experienced severe forest fires due to changes in the character of the El-Nino natural phenomenon, which became more frequent (Anggraini and Trisakti 2011). Meanwhile, research conducted by Komala (2006) shows that forest fires in Sumatra and Kalimantan are closely related to climate change due to increased ozone concentrations in the troposphere. Changes in ozone concentration are one of the factors that can cause several problems, one of which is changes in surface temperature (Mairisdawenti et al., 2014). In addition to affecting the vulnerability of an area to burning, changes in surface temperature values are also an indicator of the causes of climate change in an area.

\subsection{Hotspot Point}

Hotspot, by definition, can be defined as an area that has a relatively higher surface temperature than the surrounding area based on a certain temperature threshold monitored by remote sensing satellites. The typology is a point and is calculated as a number, not an area. The hotspot is the result of the detection of forest/land fires at a certain pixel size (for example, $1 \mathrm{~km} \mathrm{x} 1 \mathrm{~km}$ ), which may burn when the satellite passes in relatively cloud-free conditions using a certain algorithm. Usually used as an indicator of land and forest fires in an area, so the more hotspots there are, the more potential incidents of land fires in an area.

When a land/forest fire occurs in a location, it can be detected by satellite in one hotspot point, two fire events within a $500 \mathrm{~m}$ radius can be detected by only one hotspot, on the other hand, very large fire events can be detected as four or more hotspots. This illustration illustrates that hotspots are not the same as the number of land and forest fires in the field. Also, what needs to be considered regarding hotspots is the coordinates of the hotspot. The coordinates of the hotspot location extracted from satellite data do not always match the coordinates of the location in the field. One of the reasons is because the position of the coordinates of the hotspot location from the satellite data is extracted at the center of the pixel. Therefore, if there is a forest fire incident in the field which is at the edge of the pixel, the coordinates to be extracted by the satellite are the center position of the pixel (Roswintiarti 2016). 


\subsection{Human Activity}

Forest fires were originally thought to occur naturally, but humans have played a role in starting fires in the last millennium, hunting, and subsequently clearing agricultural plots in the forest. In fact, according to Saharjo and Putra (2017), the large forest fires in Indonesia that occurred in 1997 and 1998 were caused $99 \%$ by human actions while the rest were natural factors. Economic losses due to forest and land fires in that year were estimated at US \$9.3 billion (Sakti 2005) to the US \$ 20.1 billion (Varma 2003), and an estimated 35 million people were affected (Suyanto et al. 2004). At the time of the fires in 1997, the national mass media reported that 176 companies were accused of burning forests in clearing land, 133 of which were plantation companies. Although fires have characterized Indonesia's forests for hundreds of years, fires that occur initially are certainly smaller and more widespread in terms of frequency and timing than in the past two decades (Hunawan 2016). Therefore, plantation development is one of the causes of forest fires covering an area of 10 million hectares with economic losses of up to the US $\$ 9.3$ billion (Cahyono et al., 2015).

\section{Research Methods}

\subsection{Stages of identifying parameters and its processes}

The parameters used to determine the composition of this analysis must be known To understand methods for analyzing and mapping land fire vulnerability and all of those processes. The stages that can be taken to analyzing and mapping of land fire vulnerability was as follows in Figure 2.

Figure 2. The identification of components and its processes of analyzing and mapping land fire vulnerability

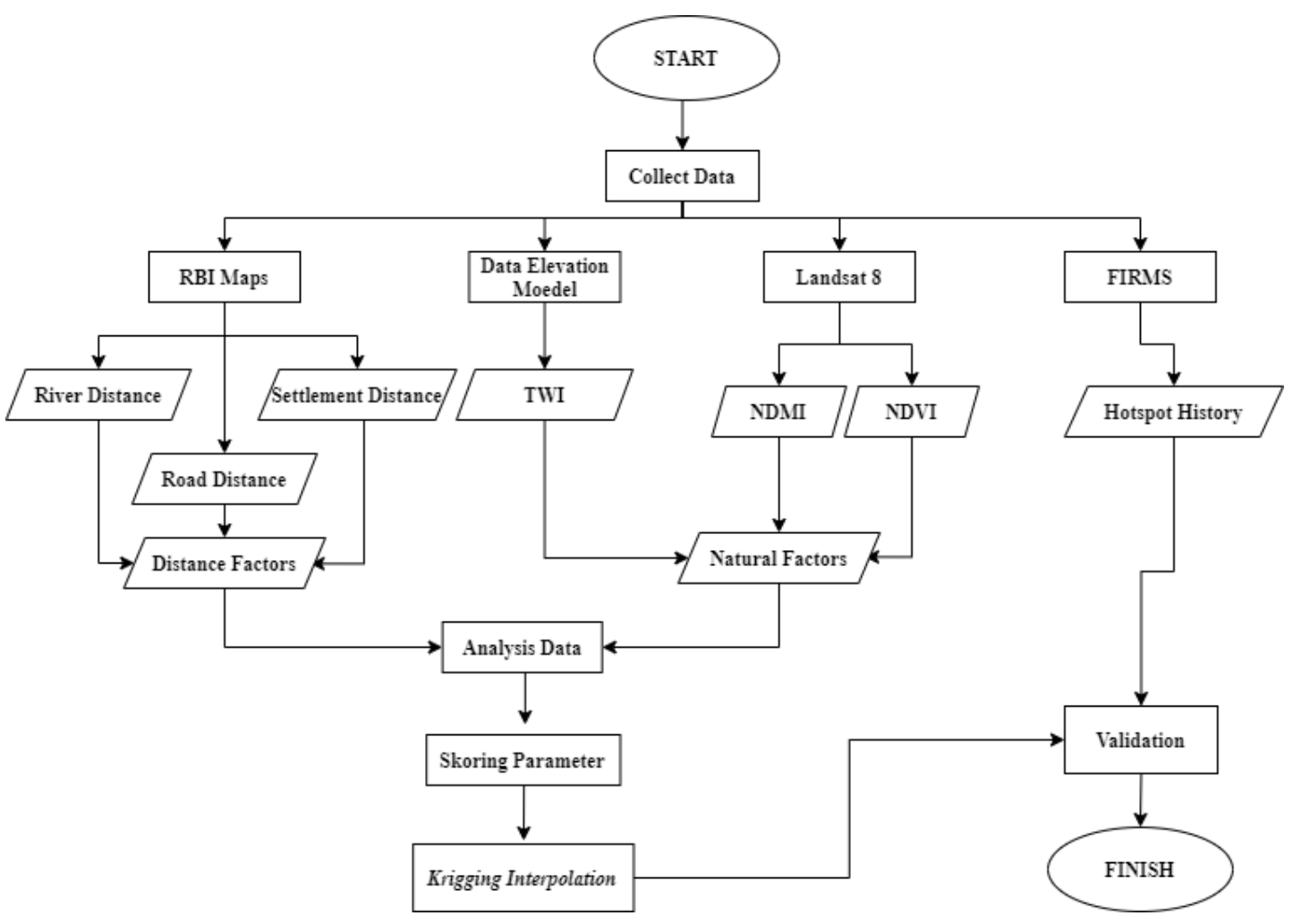


Table 1. Source and range for all parameters in analyzing and mapping land fire vulnerability

\begin{tabular}{llll}
\hline No & Parameters name & Data sources & $\begin{array}{l}\text { Time and } \\
\text { range }\end{array}$ \\
\hline 1 & Land Use & Bing Satellite & $\begin{array}{l}\text { December } \\
21,2019\end{array}$ \\
\hline 2 & NDVI (Normalized & Landsat 8 Satellite & 2020 \\
& $\begin{array}{l}\text { Difference Vegetation Index) } \\
\text { NDMI (Normalize Difference }\end{array}$ & & \\
& $\begin{array}{l}\text { Moisture Index) } \\
\text { TWI (Topographic Wetness }\end{array}$ & & \\
& Index) & Peta Rupa Bumi Indonesia & $2013-2017$ \\
\hline 3 & Distance point from & $1: 50.000$ & $2015-2019$ \\
\hline 4 & accessibility and settlement & Aqua and Terra Satellite & \\
\hline
\end{tabular}

3.2 Processing of each parameter

Map formation is based on the value of each constituent parameter. Processing and analysis of each parameter will be the characteristics of the map to be produced. The explanation of each parameter is as follows:

\subsubsection{Land Use}

This parameter is a description of several activities carried out by the community in the area. Land use is divided into four classes, namely forest land, plantation land, garden forest land, and degraded land. The class determination was carried out by manual digitation using a base map with a high level of spatial resolution issued by the Bing satellite on December 20, 2019.

\subsubsection{NDMI (Normalize Difference Moisture Index)}

The surface moisture index is used to evaluate the different humidity of the elements of a landscape. Jin and Sander (2005) stated that the humidity value or NDMI (Normalized Difference Moisture Index) could be calculated from the channel with near-infrared and shortwave sensors. In Landsat 8 imagery, NDMI is obtained from channel 5 and channel 6. The model that can be used for NDMI calculations can be seen in the equation below.

$$
\text { NDMI }=\frac{\text { Band 5 }- \text { Band } 6}{\text { Band 5+Band } 6}
$$

\subsubsection{NDVI (Normalized Difference Vegetation Index)}

The vegetation index (NDVI) is a representation of the level of the greenness of the vegetation. Rushayati et al. (2011) stated that NDVI is basically obtained from the calculation of the amount of solar radiation absorbed by plants, especially the leaves. NDVI values can be calculated from channel 5 and channel 4 analysis using equation (5) (Sahu 2014).

$$
\text { NDVI }=\frac{\text { Band } 5-\text { Band } 4}{\text { Band } 5+\text { Band } 4}
$$




\subsubsection{TWI (Topographic Wetness Index)}

The TWI method can be used to see the spatial distribution of hydrological conditions in an area (Nucifera and Putro 2017). This parameter can be searched using analysis based on the topography of an area from the Digital Elevation Model satellite.

\subsubsection{Distance from road}

The distance from the road can be obtained from the results of road tracking and delineation using several mobile applications, then the location distance from the road can be calculated. The road is meant to be the main road with a road width sufficient to accommodate two cars. The closer the area to the road, the greater the vulnerability of the land to burning. Vice versa, the farther the area is from the road, the less vulnerable the land is to burn.

\subsubsection{Distance from river}

The distance from the river is obtained from the 1: 50,000 Indonesian Earth Map data, which can provide spatial results in the form of river paths in the study area. From the river path, it can be obtained the distance of an area so that it can be given the level of vulnerability. The closer an area is to a river, the greater the vulnerability of the land to burning. Conversely, the farther the area from the river, the less susceptible the land is to burn.

\subsubsection{Distance from settlement}

Settlement data is obtained from settlement shapefile data that has been obtained from village shapefile data. Data can also be generated from regional delineation so that the resulting data is more actual. After obtaining settlement data, the value of the distance between the study area and the settlement can be obtained using image processing analysis.

\subsection{Analysis and mapping of fire vulnerability}

The formula used in this study uses a weighting system. High weight (0.9) is used for variables categorized as triggering factors of fire-related to humans, and low weight (0.1) for variables categorized as triggering factors of fire-related to natural conditions (Adinugroho et al. 2005). After each parameter is calculated and weighted, a fire vulnerability map can be arranged according to the function:

$$
\text { Fv }=0.1 \times(\text { NDVI+NDMI+TWI })+0.9 \times(\text { LU+RoD+RiD+SD })
$$

Where Fv is the result of land fires vulnerability, NDVI is the Normalize Difference Vegetation Index; NDMI is the Normalize Difference Moisture Index, TWI is the Topographic Wetness Index, LU means land use; RoD is the distance point from the road, RiD mean distance between point and river, and SD is distance point form any settlement.

The percentage of each parameter is determined based on a literature study, which shows how much the contribution of each parameter in determining the susceptibility of an area to burn. The fire vulnerability score is classified into very vulnerable, vulnerable, normal, safe, and very safe grade classes. Class division is carried out using the mean and standard deviation of point data for each constituent parameter, as shown in Table 2 below. 
Table 2. Class division from analyzing and mapping of land fires vulnerability with hotspot history relation

\begin{tabular}{cc}
\hline Skor $\mathbf{y}$ & Risk Level \\
\hline $\begin{array}{c}\text { ymax } \leq \mathrm{y}<\frac{\mathrm{ymax}+\mathrm{yQ3}}{2} \\
\frac{\mathrm{y} \text { max }+\mathrm{yQ3}}{2} \leq \mathrm{y}<\frac{\mathrm{yQ3}+\mathrm{ymedian}}{2}\end{array}$ & Very vulnerable \\
$\frac{\mathrm{yQ} 3+\mathrm{ymedian}}{2} \leq \mathrm{y}<\frac{\text { ymedian }+\mathrm{yQ} 1}{2}$ & Vulnerable \\
$\frac{\mathrm{ymedian}+\mathrm{yQ} 1}{2} \leq \mathrm{y}<\frac{\mathrm{yQ} 1+\mathrm{ymin}}{2}$ & Normal \\
$\frac{\mathrm{yQ1}+\mathrm{ymin}}{2} \leq \mathrm{y}<\mathrm{ymin}$ & Safe \\
\hline
\end{tabular}

The hotspot value used has a confidence level of more than the same as $80 \%$. The selection of the level of the confidence interval is based on a guidebook for analyzing hotspot and forest fire area data published by the Ministry of Environment and Forestry in 2016, which explains that the highest probability of detecting indications of forest and land fires in the field is at hotspots with a confidence level of more than $80 \%$ to $100 \%$.

\section{Results and Discussions}

\subsection{Research Field}

The research area in this mapping is in the villages of Jebus, Sungai Aur, and Gedong Karya, which are located in Kumpeh District, Muaro Jambi Regency. The research location has an area of $88.762,61$ hectares, which is divided into three villages. Sungai Aur is the village with the largest area in the study area. Most of the area is still covered by forest, but several points have begun to be used by the community for plantations, including oil palm, vegetable and fruit plantations, or other plantations. This area is also traversed by a network of rivers originating from the Batanghari river and utilized by the community for transportation, land irrigation, to meet their needs by fishing and shrimp around the river. Most of the communities in the study area are farmers, fishermen, and plantation employees. The majority of the plantation land is planted with oil palm, maize, nuts, and rice. Community activities are centered in gardens, rice fields, rivers, fields, and village halls. In the eastern part of Taman Hutan Rakyat, there is a transmigrant settlement, which was opened in 2010 with a total of 130 hectares and is under the supervision of Sungai Aur village. As the settlement closest to the Taman Hutan Rakyat, the transmigrant settlement was associated with fires that routinely occur in the Taman Hutan Rakyat area. 


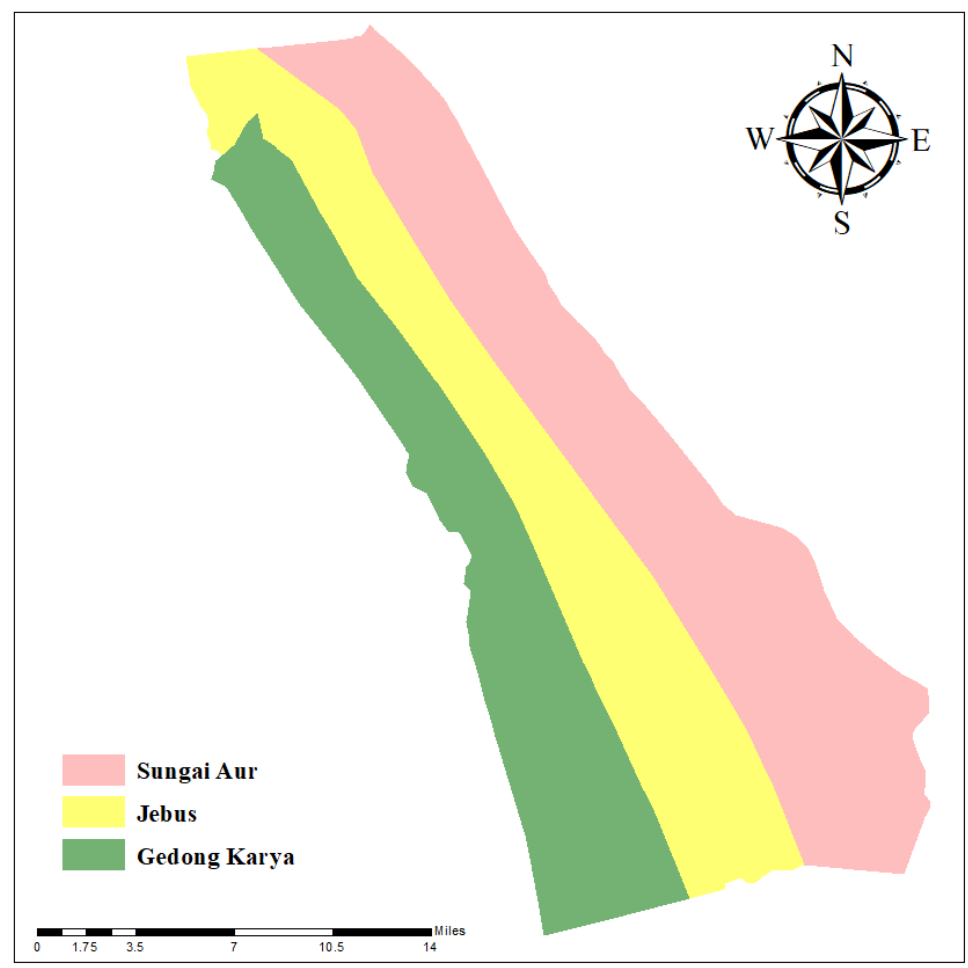

Fires in the data collection area always started in the Taman Hutan Rakyat area and community land in the eastern part of one of the oil palm plantation companies. The fires, which always occur every year, reached their peak in 2015 and 2019, marked by their tremendous impact on a regional to a national scale. Hotspot data or hotspots that can be used as the main indicator for knowing the presence of fires (Vetrita et al. 2014) provide additional evidence of the fire history of the study area.

\subsection{Parameters}

\subsubsection{Land Use}

The land use map in the Kumpeh area, especially in the villages of Jebus, Gedong Karya, and Sungai Aur, is divided into four types, namely forest land, plantation land, garden forest land, and degraded land. Forest land depicts dense tree vegetation with irregular positions consisting of various types of vegetation. Plantation land is an area that is dominated by plantation vegetation such as vegetables and fruits, including rice fields. Plantation forest land is an oil palm plantation with various heights and ages, which can be recognized as tall vegetation with an orderly position and consists of only one type of vegetation. Degraded land describes land that has been damaged due to land-use change, burning, or river erosion. 


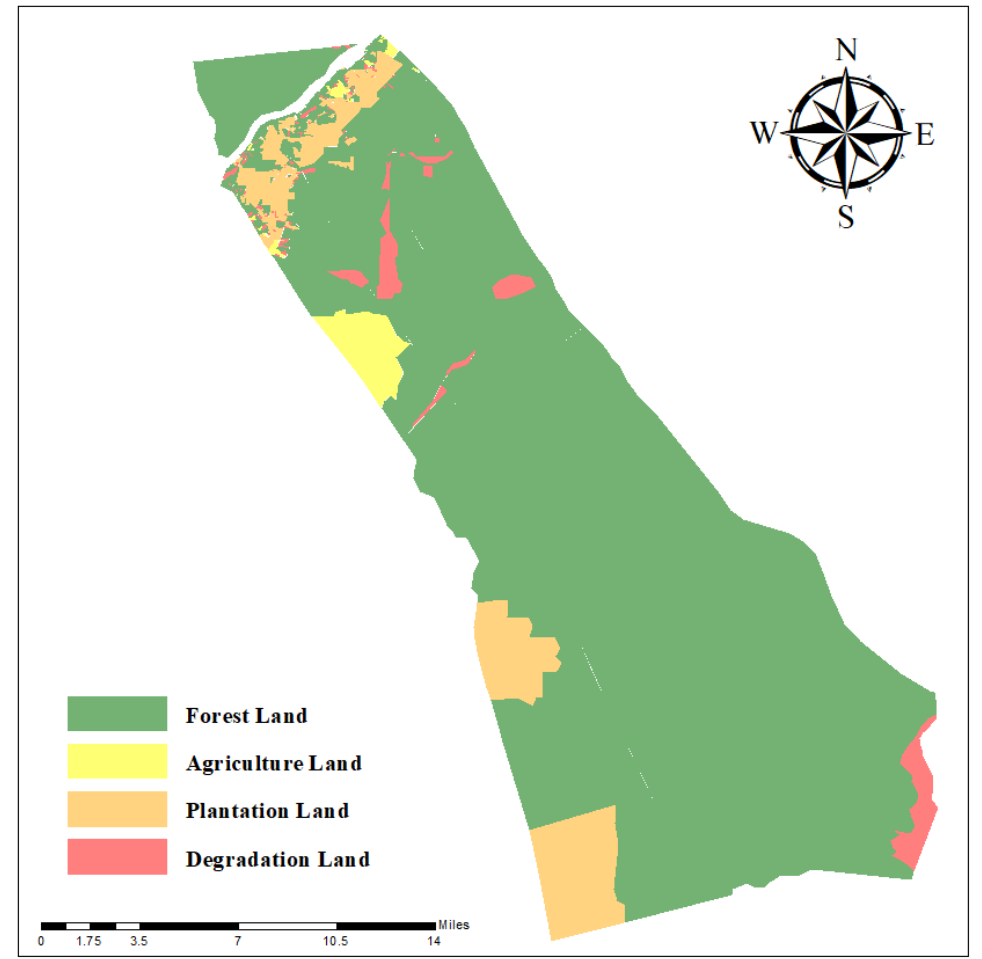

Forest land became the area with the highest proportion $(86.47 \%)$ in the study area, while agricultural land was the area with the lowest area (1.98\%). As an area far from community settlements, the eastern and southern parts of the study area are dominated by dense forest which is divided by several tributaries. The areas of degradation (2.62\%) are not only in residential areas but also spread over several areas surrounded by forests that are far from community access. Besides, at some points of degraded land that are far from river access, there is no plantation land, either oil palm plantations or plantations with other vegetation. This needs to be investigated further to know the background of the fires at these points.

Table 3. Area of each land use

\begin{tabular}{llrc}
\hline No & Land use & Capacious $(\mathbf{H a})$ & Percentage $(\%)$ \\
\hline 1. & Forest land & 76591.72 & 86.47 \\
2. & Agriculture & 1754.95 & 1.98 \\
3. & Palm oil plantation & 7295.87 & 8.23 \\
4. & Degradation & 2322.98 & 2.62 \\
\hline
\end{tabular}

In preparing this fire vulnerability map, each type of land use has a different value based on its characteristics. Forest land and oil palm plantations have a low vulnerability value because these areas are generally far from access. Apart from that, from a wellmaintained management perspective, it can also reduce the possibility of the two types of land use being burned. Agricultural land has a high vulnerability value, based on the fuel farming system, which is generally applied in the study area. Meanwhile, degraded land has the highest fire vulnerability value due to its low quality of management and supervision as well 
as high historical burns. Also, degraded areas generally have low land cover, such as low grass or shrubs that are easy to burn.

\subsubsection{NDVI (Normalized Difference Vegetation Index)}

The vegetation index is an algorithm that is applied to digital images that aim to highlight vegetation aspects such as density, type, age, or other aspects related to vegetation (Armanto 2013). One of the most commonly used penile techniques is the Normalized Difference Vegetation Index (NDVI).

Figure 5. Normalize Difference Vegetation Index map

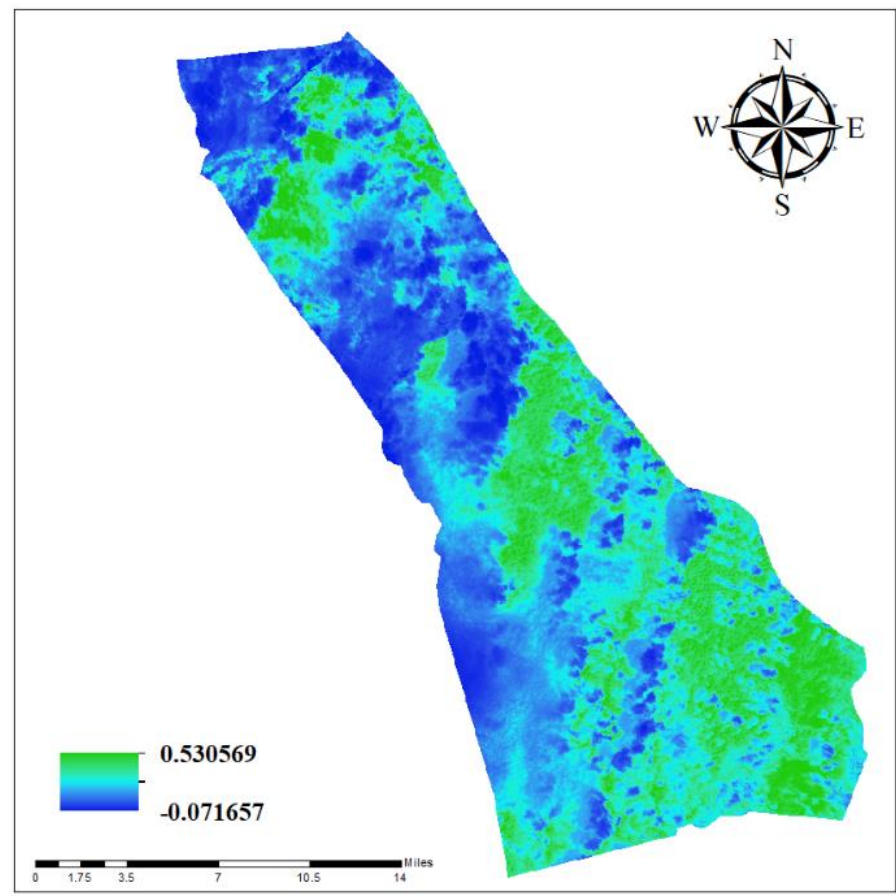

A low NDVI value indicates that the vegetation density is getting worse (Putra et al., 2017). However, a high NDVI value does not mean that the area has a low fire history. This is shown in the southern part of the study area with high NDVI values, but also a history of high hotspots. Based on the explanation from Rusman (2020) in the interview, it is known that high vegetation values can be one of the causes of the high history of fire in the area due to the large amount of fuel available. Even when a fire occurs, the greener an area is, the harder it is to extinguish because fire has a longer lifetime when burning green plants than when burning dry plants.

\subsubsection{NDMI (Normalize Difference Moisture Index)}

Moisture is the water content that plays an important role in the functioning of vegetation. This is because leaves are the place where photosynthesis generally occurs, most of which is water (Bell 2011). 


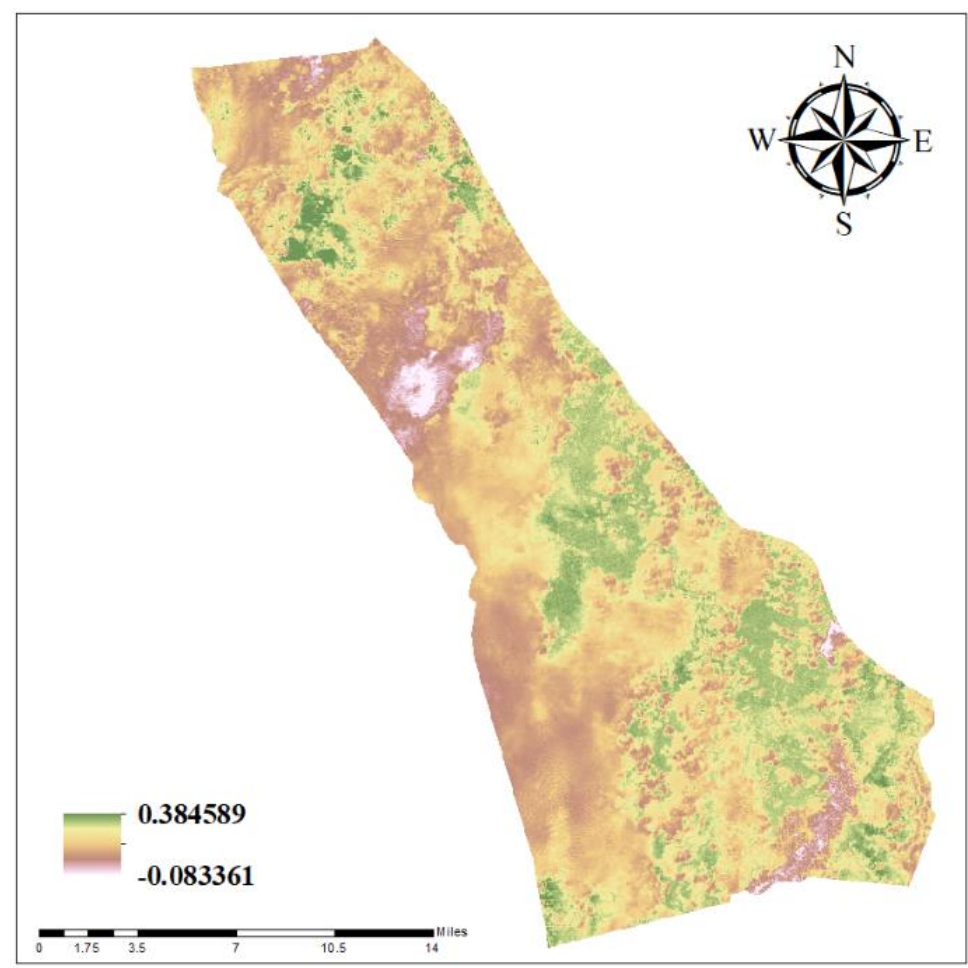

NDMI values range from -1 to 1 , with low values indicating low humidity levels and vice versa, high NDMI values indicate high humidity levels (Achmed et al. 2018). Based on his research, the study area above has a very low classification of NDMI values to very high classifications. The NDMI value has a positive relationship with NDVI, which can be concluded that the higher the NDVI value, the higher the NDMI value, and vice versa if the NDMI value is low, the NDVI value will be lower. Most of the low NDMI values are in agricultural and plantation areas. Meanwhile, several points with low NDMI were also found in several forest areas and degraded lands.

\subsubsection{TWI (Topographic Wetness Index)}

Topographic Wetness Index (TWI) is a topographic control quantification method of the hydrological process (Pourali et al., 2014). The spatial distribution of hydrological conditions can be mapped using this method. TWI quantitatively assesses the effect of local topography on rainwater runoff and the trend of water accumulation on a slope (Nucifera and Putro 2017). 
Figure 7. Topographic Wetness Index map

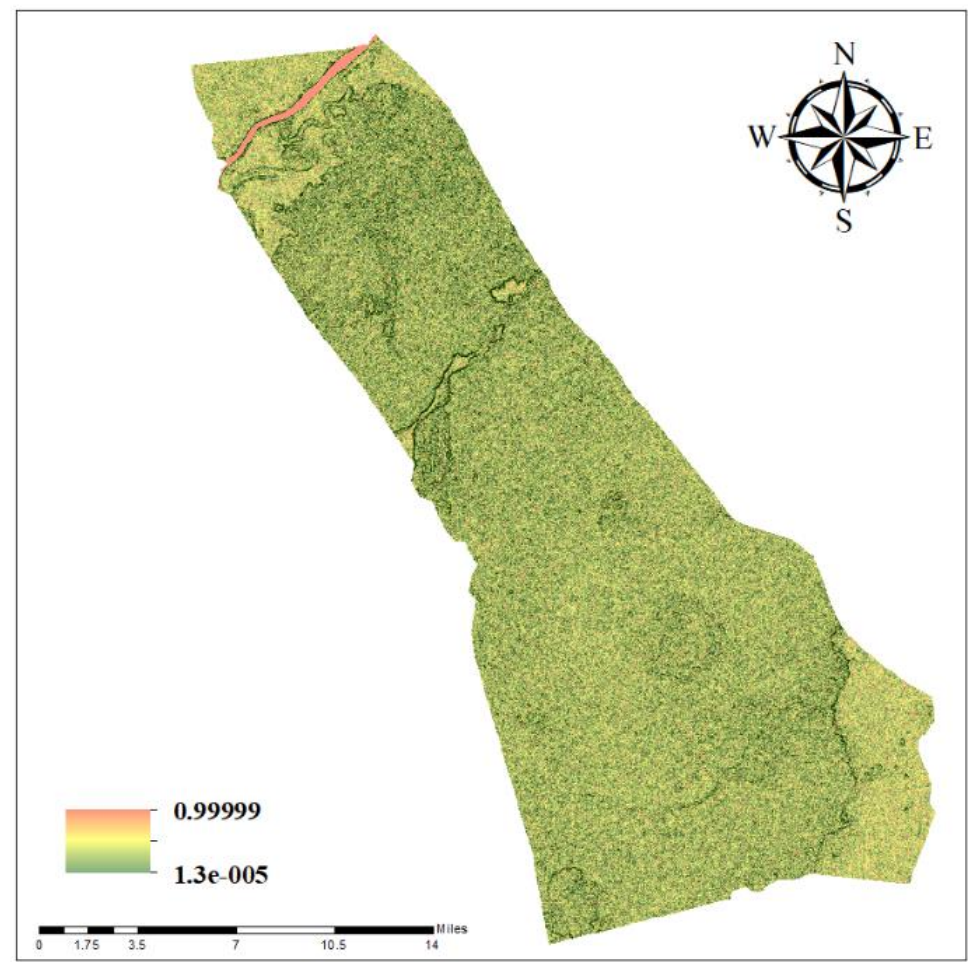

Topographic Wetness Index values that have been normalized are in the range of 0 to 1. The study area has a flat topography marked by a uniform TWI distribution in each area. The greater the TWI value indicates that the area is an area of water accumulation. However, a high TWI value cannot be a rule that the area is far from the fire. This can be seen in the northern part of the study area, which has a high TWI value but also has a history of high hotspots.

\subsubsection{Road Distance}

The area distance from accessibility is divided into two, namely the area distance from roads and rivers. The types of roads used are main or arterial roads, collector roads, local roads, footpaths, and other roads. 


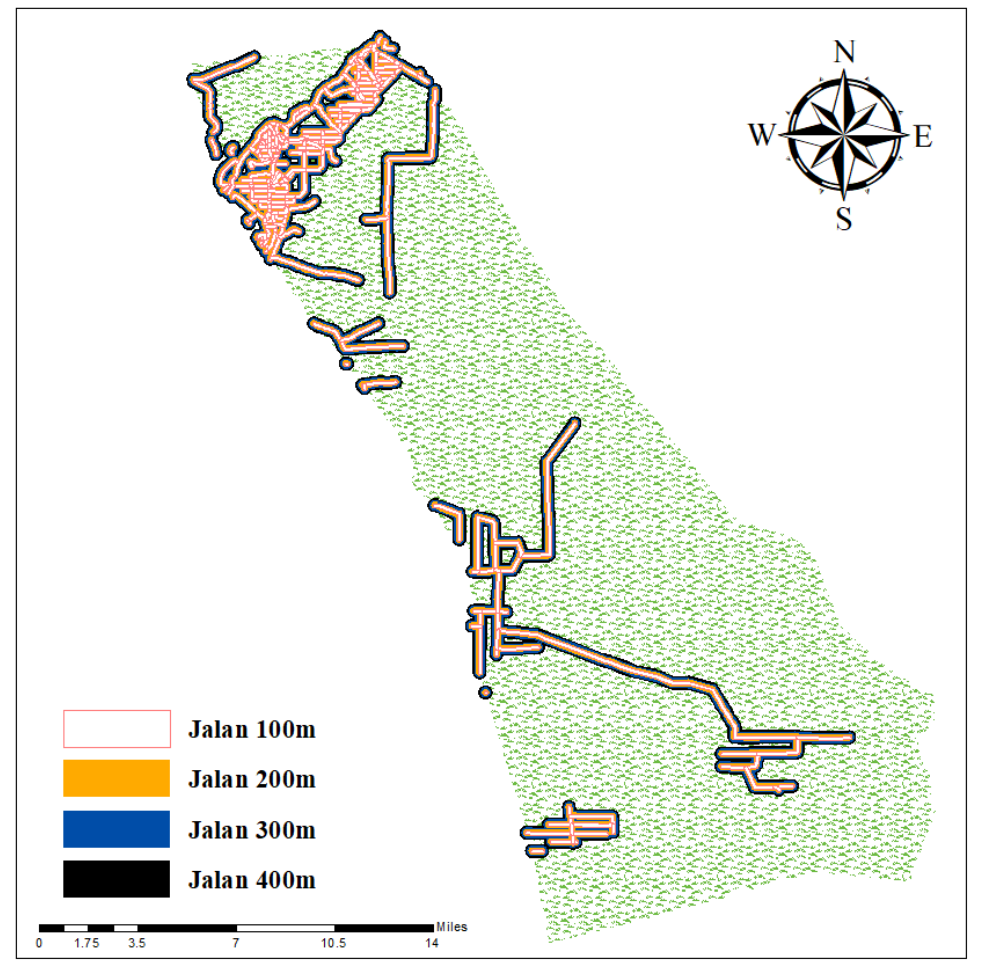

The road network obtained from the Indonesian Earth Map is buffered by 1000 meters to 4000 meters. The classification is based on research by Jaiswal et al. (2002), who divided the distance into five classes. The provision of buffer classes for this road network is carried out because as an area with a high threat of logging activities, road access is an important aspect of regional delivery. The interview conducted also yielded information that logging was the main cause of the fires that occurred in 2019 because several pieces of ready-totransport wood were found left after the fire was extinguished.

In Mapilata's (2013) study, the distance from the road of fewer than 1000 meters is an area with a high level of vulnerability, while research conducted by Mahrus et al. (2017) provides a fairly close positive correlation between the distance of the road network and historical hotspots in the PT. Inhutani II. However, in the map above, after comparing it with the hotspot map, it will be found that only a few road networks are adjacent to areas with hotspot history. Types of road networks that are close to areas with a fire history are other roads and trails.

\subsubsection{River Distance}

The type of river used is in the form of small rivers and irrigation canals formed from large rivers such as the Batanghari River around the study area. Apart from being one of the community's accessibility pathways, rivers can also be a medium for transporting forest products by being washed away to facilitate transfer from areas far from the road network. 
Figure 9. River distance map

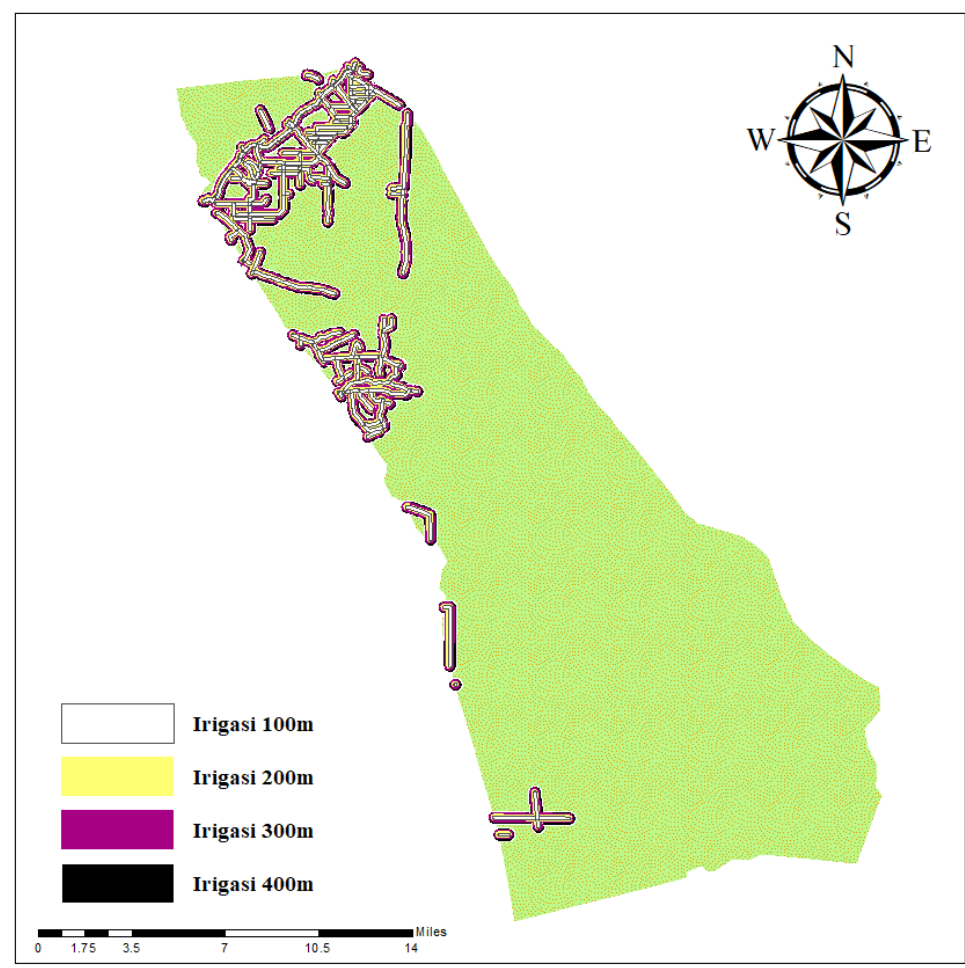

The river and canal networks in the study area are divided into five classes after a buffering of 100 meters to a buffer of 400 meters. At several river points in the study area, several patrol boats from the Peatland Restoration Agency to police boats patrolling narrow canals. Most of the areas that are close to the river network are agricultural, plantation, and residential areas. Meanwhile, the southern and southeastern areas, which do not have many rivers, are dominated by forest areas.

\subsubsection{Settlement Distance}

The center of community activity in this study is in the form of settlements that are inside and outside the study area. The data were obtained from the attribute data for the Indonesian Earth Map at a scale of 1: 50,000. Adinugroho et al. (2005) explained that forest and land fires are more caused by human activities that can withstand areas where community activities are carried out. 
Figure 10. Settlement distance map

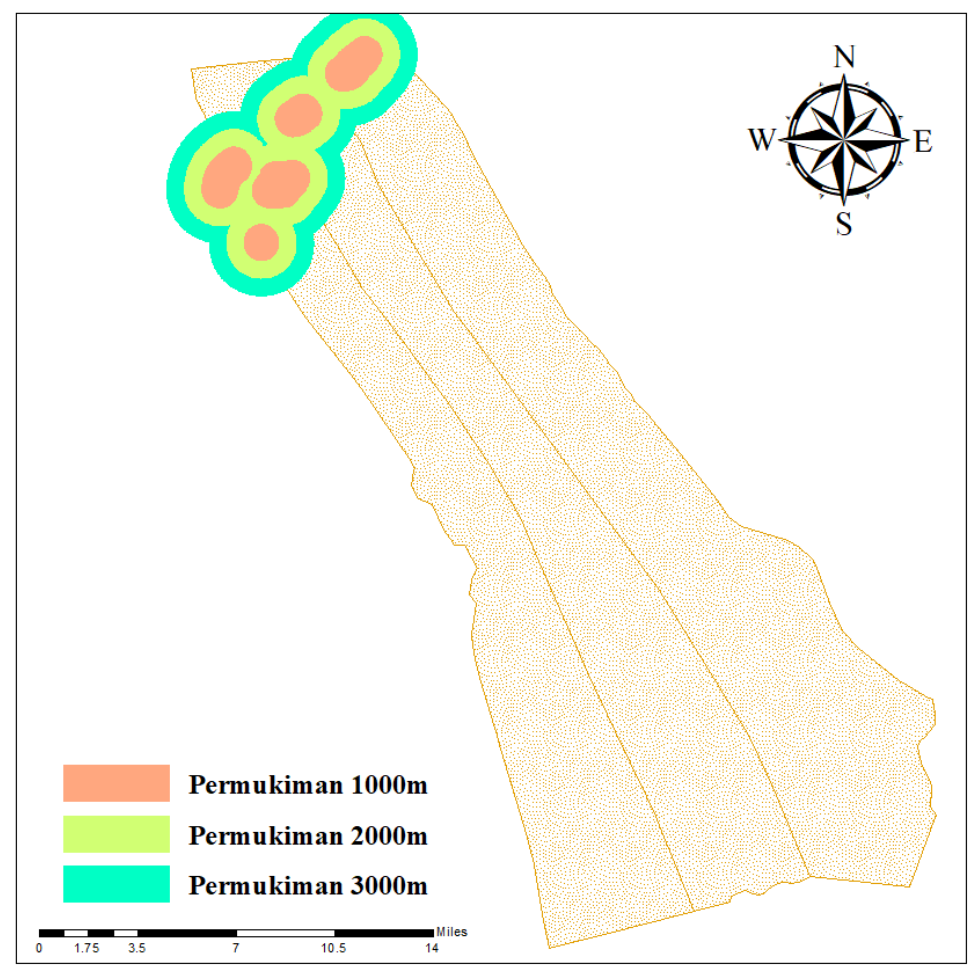

From each available settlement point, buffering is carried out of 1000 meters to more than 3000 meters. Soil speculators are one of the motivations for burning land where land that tends to be clean will be valued higher as well as a sign that the land has an owner (Solichin et al. 2007). The results of the field interviews also indicated that the distance from the settlement had a big influence on the incidence of fires in the study area in previous years.

But in the map in Figure 10, the results are a little surprising. At each settlement point and available buffer, a very little history of hotspots exists in the buffers above. Even so, not far from the settlement buffer, but outside the buffer, many hotspots were scattered. The provisional conclusion from the above incident is that in the case of this study, the role of the community in burning land and forest is very small, or if the community does fire, the distance from the burning point is more than 3000 meters from the residential area. Most of the areas in the buffer are agricultural and plantation areas, either owned by the community or by a company.

\subsection{Fires Vulnerability Map}

The results of the analysis of the vulnerability of an area use the value of the data received at each observation point. The value of each meteorological factor has a different weight by referring to several literature studies in the preparation of this fire vulnerability map. A high value indicates the high vulnerability of an area so that the score is five if the risk value is very vulnerable and vice versa, the score is one of the vulnerability value is very low. Based on these calculations, the risk level class is obtained, which can be seen in Table 3 below. 
Table 4. Fire vulnerability class

\begin{tabular}{cc}
\hline Score of $\mathbf{y}$ & Risk Level \\
\hline $\mathrm{y}<2.41$ & Very vulnerable \\
$2.41 \leq \mathrm{y}<2.70$ & Vulnerable \\
$2.70 \leq \mathrm{y}<2.94$ & Normal \\
$2.94 \leq \mathrm{y}<3.16$ & Safe \\
$\mathrm{y} \geq 3.16$ & Very safe \\
\hline
\end{tabular}

After knowing the score value at each point, the point data are interpolated using the Kriging interpolation method. This method is used because the observational data obtained matches the characteristics of the data required in the preparation of kriging interpolation, namely the spatial correlation data of the distance and orientation of the data. By using the assumption of distance and orientation between the data samples showing an important spatial correlation (Pramono 2008), this method is deemed suitable in presenting the results of observations in spatial form. The interpolation results are shown in Figure 11 below.

Figure 11. Land and forest fires vulnerability map based on natural parameters

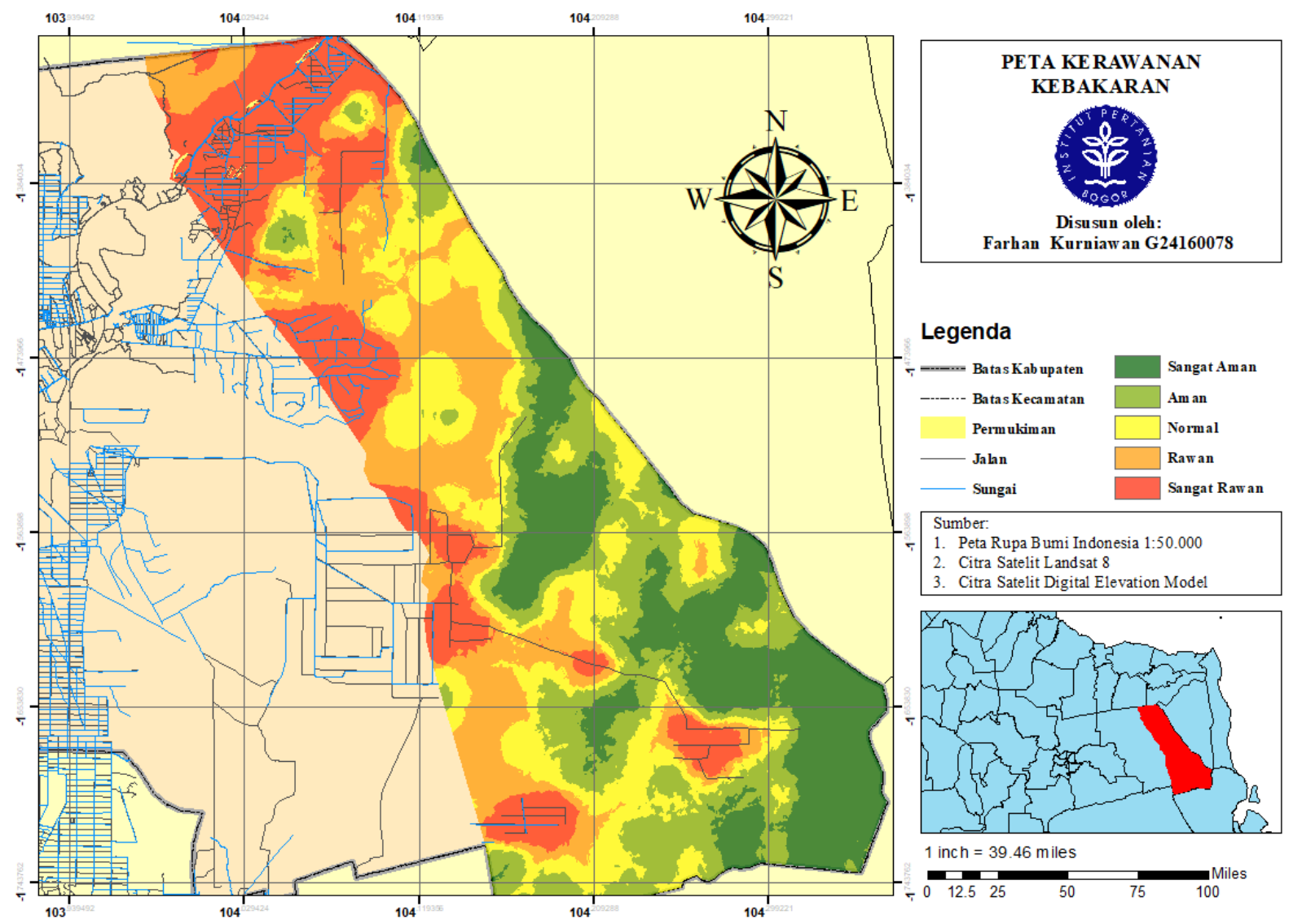

Areas with high vulnerability values are in areas dominated by high accessibility, as shown along the northern part of the study area. This area has a fairly close distance from all types of accessibility, which are used as parameters in this study, such as road access, rivers, and settlements. Several points with high vulnerability also show that there is access in and out of the area either through road or river networks. This is due to the large weighting values given to these parameters in the preparation of this map. Most of the areas with high vulnerability are agricultural and plantation areas. Meanwhile, in the southeastern part of 
Sungai Aur village, the majority of areas have a low vulnerability, apart from the absence of a river or road network, which is also due to the high value of natural parameters. Even though it only has a small weight, this parameter also contributes to the level of vulnerability of an area. Some points with high enough vulnerability are also affected by low natural parameter values. Most of the land with a low level of vulnerability is forest area.

The results of the equation and the weighting of each parameter for the fire vulnerability map produce the area size and its percentage of the total area of the study area, as shown in Table 5 below.

Table 5. Area and percentage of vulnerability class

\begin{tabular}{ccc}
\hline Risk Level & Capacious (ha) & Percentage (\%) \\
\hline Very vulnerable & 17873.06 & 20.18 \\
Vulnerable & 18375.41 & 20.75 \\
Normal & 17322.87 & 19.56 \\
Safe & 17504.51 & 19.76 \\
Very safe & 17686.76 & 19.97 \\
\hline
\end{tabular}

\subsection{Fire Vulnerability with Hotspot History}

This study uses hotspot data with a confidence interval of above $80 \%$ accessed from MODIS imagery (Aqua and Terra satellites). According to Vetrita et al. (2014), MODIS FIRMS data source with various confidence levels provides the highest level of accuracy compared to other data sources. Meanwhile, the selection of the level of the confidence interval is based on a guidebook for analyzing hotspot data and forest fire areas published by the Ministry of Environment and Forestry in 2016, which explains that the highest probability of detecting indications of forest and land fires in the field is at hotspots with a level of confidence. More than $80 \%$ to $100 \%$. So in this study, the level of confidence interval at available hotspots will be divided into three classes, namely hotspots with a confidence interval of $80 \%, 90 \%$, and finally $100 \%$.

Figure 12. Hotspot history map from 2015-2019

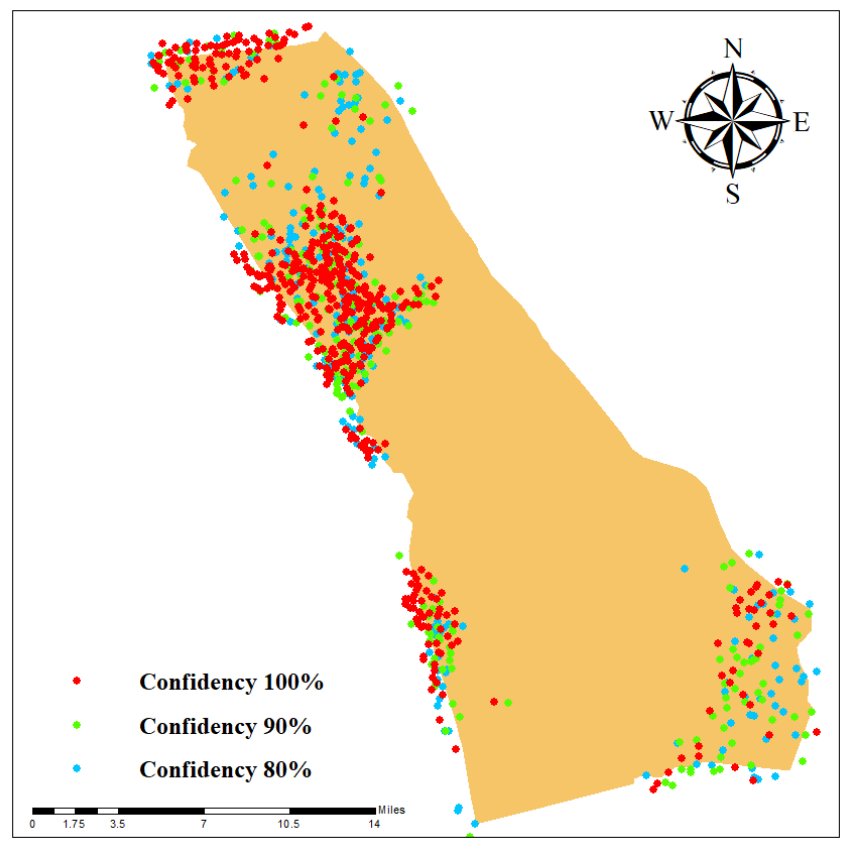


Figure 12 shows cluster hotspots scattered in different parts of the study area. Cluster hotspots represent a land fire large enough to spread its heat effect to other areas (Roswintiarti 2016). The existence of cluster hotspots ensures that there is a fire in the area. In the eastern part of the study area, cluster hotspots have high concentrations so that the area has a fairly large fire history. In the west and northwest, hotspot concentrations are very thick. This indicates that there has been a fairly high-intensity fire in the area. The southeastern part of the map shows that the hotspots are scattered with low concentrations so that the area, although it has a lot of history of burning, the intensity of land fires that occurs is not as high as in the case of the western region.

Figure 13. The relation between fire vulnerability with hotspot history

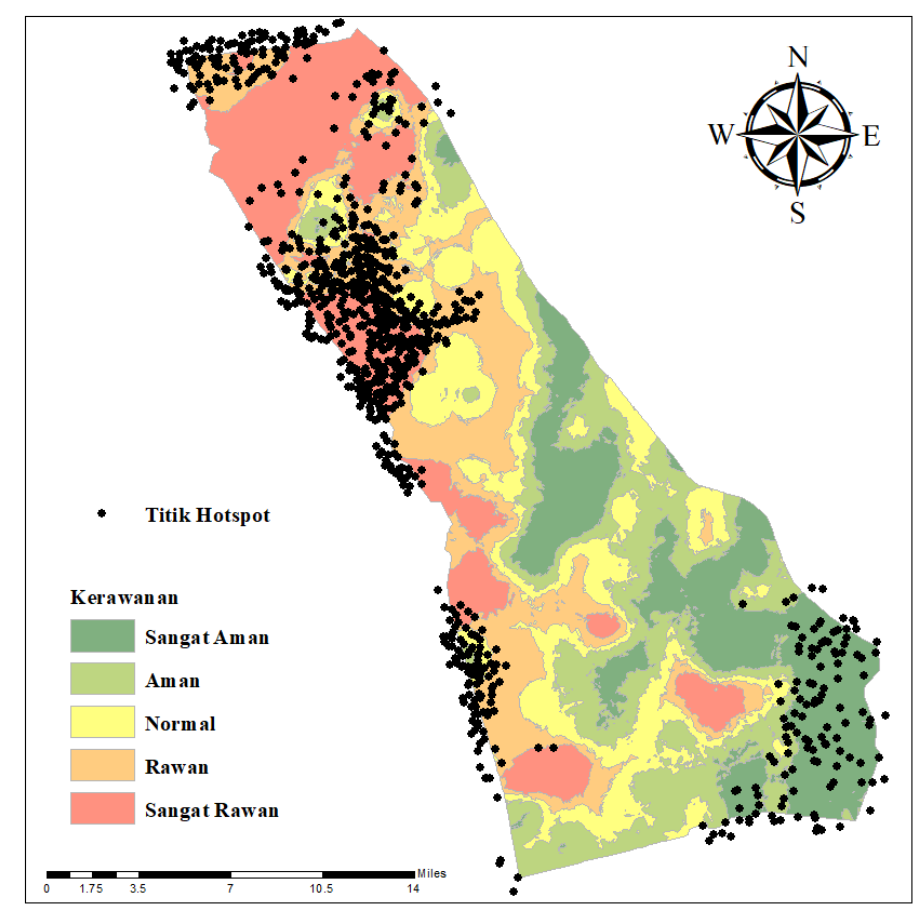

The concentration of hotspots is spread over several map points. The north and west are the regions with the highest burns history. Each of these areas is dominated by areas with high vulnerability. Meanwhile, in the southeastern part of the map, the concentration of hotspots spreads over areas with a low risk of burning predominance. The results of the previous map overlay with the distribution of hotspots show that areas with a high level of vulnerability have the most host history, followed by very vulnerable areas with a small difference in numbers. Safe areas are the areas with the lowest number of hotspots. Areas with a very safe level of vulnerability have hotspot values that are high enough to prove that the cause of a fire is still not completely mapped. Besides, the interaction aspect of the surrounding community has not been included in the calculation of this model.

Table 6. Vulnerability map with hotspot history relation

\begin{tabular}{cc}
\hline Risk Level & Jumlah Titik Hotspot \\
\hline Very vulnerable & 268 \\
Vulnerable & 269 \\
Normal & 72 \\
Safe & 23 \\
Very safe & 76 \\
\hline
\end{tabular}




\section{Conclusions and Recommendations}

Forest and land fires in Indonesia have received international attention. Geographical information systems and remote sensing have long been used to support forest fire control. One form of its use is to develop a fire vulnerability map. Through this map, monitoring and fire prevention activities can be carried out as early as possible. In this research, as much as $20.18 \%$ of the study area has a very vulnerable level, $20.75 \%$ at a vulnerable level, $19.56 \%$ at a normal level, $19.76 \%$ at a safe level, and $19.97 \%$ at a very safe level. Most of the areas with a very vulnerable level have high accessibility and activity centers. Also, the area is dominated by agriculture and plantations with low natural parameter values. The formula used in the fire vulnerability map modeling has a high enough correlation. This can be seen from a large number of hotspots in areas with vulnerable and very vulnerable classes, which is more than $75 \%$ of all percentages. The large difference between the number of hotspots in the vulnerable and safe classes is also the result of a fairly good correlation between models and events in the field. This formula gives a high value to the accessibility parameter as the main cause and the natural parameter to support the occurrence of fire.

Fire vulnerability maps are used to provide information on the potential burns of an area. From this goal, it is hoped that an efficient disaster management system is formed based on the level of vulnerability in an area so that the intensity of fires can be reduced each year. Based on the results of this research, the authors suggest that the government and its staff need to pay attention to areas of high vulnerability, such as the northern part of the villages of Jebus, Gedongkarya, and Sungai Aur. The western area of the village of Gedongkarya also deserves to be monitored, considering the level of vulnerability, as well as the history of hotspots in the area, is very high. Fire suppression facilities from areas of low vulnerability can be partially diverted to assist in overcoming high hazard areas. 


\section{BIBLIOGRAPHY}

\section{Book}

[BNPB] Badan Nasional Penanggulangan Bencana. 2013. Rencana Kontinjensi Nasional Menghadapi Ancaman Bencana Asap Akibat Kebakaran Hutan dan Lahan. Jakarta.

Bell GE. 2011. Turfgrass Physiology \& Ecology: Advanced Management Principles. Cambridge: Cambridge University Press

Endrawati. 2016. Analisis Data Titik Panas (Hotspot) dan Areal Kebakaran Hutan dan Lahan tahun 2016. Jakarta: Direktorat Inventarisasi dan Pemantauan Sumber Daya Hutan

Rostiwintarti O. 2016. Informasi Titik Panas (Hotspot) Kebakaran Hutan/Lahan. Jakarta: LAPAN

Solichin L, Tarigan P, Kimman, Firman B, and Bagyono R. 2007. Pemetaan daerah rawan kebakaran. Palembang. SFFM

Suyanto, Chokkalingan U, and Wibowo P. 2004. Kebakaran di lahan rawa/gambut di Sumatera: masalah dan solusi. Di dalam: Prosiding Semiloka; 2004; Bogor: CIFOR

Syaufina L. 2008. Kebakaran Hutan dan Lahan di Indonesia; Perilaku, Penyebab, dan Dampak Kebakaran. Malang: Bayumedia Publishing

\section{Journal}

Achmed E, Hamzah, Albayudi, and Bima. 2018. "Indeks kelembaban Taman Nasional Bukit Tiga Puluh menggunakan citra satelit Landsat 8". Penggunaan dan Pengembangan Produk Informasi Geospasial Mendukung Daya Saing Nasional. Seminar Nasional Geomatika

Adiningsih ES, Kartodiharjo H, and Murdiyarso D. 2005. "Analisis kebijakan dalam pencegahan kebakaran hutan dan lahan di Sumatera.” Jurnal Wacana-Insist Edisi 20 (Jurnal Ilmu Sosial Transformatif): 9: 113-132

Anggraini N and Trisakti B. 2011. "Kajian dampak perubahan iklim terhadap kebakaran hutan dan deforestasi di Provinsi Kalimantan Barat”. Jurnal Penginderaan Jauh. 8: 1120

Arifianto F, Koesmaryona Y, and Impron. 2016. "Karakterisasi tingkat produksi duku berbasis pewilayahan hujan di Provinsi Jambi”. Jurnal Hortikultura Indonesia. 7: 121128

Arnanto A. 2013. "Pemanfaatan transformasi normalized difference vegetation index (NDVI) citra Landsat TM untuk zonasi vegetasi di lereng Merapi bagian selatan”. Gramedia. 11: $155-170$

Cahyono SA, Warsito SP, Andayani W, and Darwanto DH. 2015. "Faktor-faktor yang mempengaruhi kebakaran hutan di Indonesia dan implikasi kebijakannya". Jurnal Sylva Lestari. 3: 103-112

Hunawan D. 2016. "Menyelesaikan kebakaran hutan dan lahan (KARHUTLA) di Indonesia melalui Jalan Pantas atau Jalan Pintas". Di Dalam: Seminar Nasional Hukum; 2016; Departemen Hubungan Internasional, Fakultas Ilmu Sosial dan Politik. Yogyakarta (ID): Universitas Gadjah Mada. 2: 277-292

Jaiswal RK, Mkherjee S, Raju KD, Saxena R. 2002. "Forest fire risk zone mapping from satellite imagery and GIS". International Journal of Applied Earth Observation and Geoinformation. 4:1-10 
Jin S and Sander SA. 2005. "Comparison of time series tasseled cap wetness and the normalized difference moisture index in detecting forest disturbance". Remote Sensing of Environtment. 94: 364-372

Komala N. 2006. "Analisis hubungan antara ozon dengan temperatur (studi kasus data watukosek 1993-2005)". Di Dalam: Prosiding Seminar Nasional Lingkungan; 2006.

Mahrus A, Satriadi T, and Syam'ani. 2017. "Kecenderungan kebakaran hutan dan lahan dan alternatif pengendalian berbasis kemitraan di PT Inhutani II Kotabaru". Jurnal Hutan Tropis. 5: 222-235

Mairisdawenti, Pujiastuti D, and Firman AI. 2014. "Analisis pengaruh intensitas radiasi matahari, temperatur dan kelembaban udara terhadap fluktuasi konsentrasi ozon permukaan di Bukit Kototabang tahun 2005-2010". Jurnal Fisika Unand. 3: 117-183

Mapilata E, Gandasasmita K, and Djajakirana G. 2013. "Analisis daerah rawan kebakaran hutan dan lahan dalam penataan ruang di kota Palangka Raya, provinsi Kalimantan Tengah". Jurnal Globe. 15: 178-184

Nivo SG. 2017. "Zonasi Tingkat Kerawanan Kebakaran Di Lahan Gambut (Studi Kasus: PT. Bumi Sawit Sejahtera - Kalimantan Barat).” Essay., Institut Pertanian Bogor.

Nucifera F and Putro ST. 2017. "Deteksi kerawanan banjir genangnan menggunakan Topographic Wetness Index”. Jurnal Komunikasi Geografi. 18: 107-116

Pouralli SH, Arrowsmith C, Crisman N, Matkan A, and Mitchel D. 2014. "Topography wetness index application in flood-risk based land use planning". Application Spatial Analysis. 9: 39-54

Pramono GH. 2008. "Akurasi metode IDW dan krigging untuk interpolasi sebaran sedimen tersuspensi di Maros, Sulawesi Selatan". Forum Geografi. 22: 145-158

Putra A, Tanto TA, Farhan AR, Husrin S, and Pranowo WS. "Pendekatan metode Normalized Difference Vegetation Index (NDVI) dan Lyzenga untuk pemetaan sebaran ekosistem perairan di kawasan pesisir teluk Benoa-Bali”. Jurnal Geomatika. 23: 87-94

Rushayati SB, Alikodra HS, Dahlan EN, and Purnomo H. 2011. "Pengembangan ruang terbuka hijau berdasarkan distribusi suhu permukaan di Kabupaten Bandung". Forum Geografi. 25: 17-26

Saharjo BH and Putra ET. 2013. "Pengendalian kebakaran hutan di KPH Madiun perum Perhutani Unit II Jawa Timur". Jurnal Sivikultur Tropika. 8: 183-190

Sakti DN. 2005. "Dampak protokol Kyoto melalui Clean Development Mechanism pada sektor kehutanan terhadap perekonomian Indonesia: pendekatan sistem neraca sosial ekonomi" Thesis., Universitas Indonesia

Supriyanto, Syarifudin, and Ardi. 2018. "Analisis kebijakan pencegahan dan pengendalian kebakaran hutan dan lahan di Provinsi Jambi”. Jurnal Pembangunan Berkelanjutan. 1: 94-104

Syaufina L and Hafni DAF. 2018. "Variablitias iklim dan kejadian kebakaran hutan dan lahan gambut di Kabupaten Bengkalis, Provinsi Riau”. Jurnal Silvikultur Tropika. 9: 60-68

Ulya NA and Yunardy S. 2006." Analisis dampak kebakaran hutan di Indonesia terhadap distribusi pendapatan masyarakat”. Jurnal Penelitian Sosial \& Ekonomi Kehutanan. 3: $133-146$

Varma A. 2003. "The economics of slash and burn: a case study of the 1997-1998 Indonesia forest fires". Ecological Economics. 46: 159-171

Vetrita Y, Zubaedah A, and Khomarudin R. 2014. "Modis hotspot validation over Sumatera and Kalimantan based on remote sensing data Spot-4 in 2012". Jurnal Penginderaan Jauh. 11: 1-14

Wooster MJ, Perry GIW, and Zoumas A. 2012. "Fire, drought amd El Nino relationship on Borneo (Southeast Asia) in the pre-modis era (1980-2000)”. Biogeosciences. 9: 31734 